\title{
Main aspects, principles and targets of teaching foreign languages
}

\author{
Elena Priss ${ }^{1 *}$, and Svetlana Evtushenko ${ }^{1}$ \\ ${ }^{1}$ Don State Technical University, 344003, Gagarina sq., 1, Rostov-on-Don, Russia
}

\begin{abstract}
The language is entering the era of the information society and is undergoing changes associated with borrowing words from the dominant language. With the development of social, political, economic and cultural conditions with other societies, there is a "mixing of languages" or "language contact". This process affects the structure or vocabulary of one of the languages. Since contact occurs through the social and speech interaction of native speakers, the result is either minor changes in vocabulary or significant structural changes at all language levels. In the vocabulary of any language, there are many borrowed words, which are very diverse both in their composition and in the degree of penetration into the language they are borrowed from. Of all the units of a language phonetic, grammatical, and lexical-words are usually the most easily borrowed due to their General mobility. However, in the vocabulary of any language there are, as we already know, different "layers", different categories of words that are borrowed in different ways. The problem of borrowing in vocabulary has both a general and a particular aspect, due to the peculiarity of the relationship between different languages.
\end{abstract}

\section{Introduction}

A person's knowledge of the world is formed and exists in language. In the course of his activity, a person records the results of cognition in the language form. The totality of this knowledge is a linguistic picture of the world.

According to Z. D. Popova and I. A. Sternin, the linguistic picture of the world is the people's ideas about reality at a certain stage of its development, which are recorded in language units. In other words, the language picture of the world is information about the world, embedded in the system meanings of words [1].

The language preserves the historical experience of the entire nation. This experience is a factor that determines the features of the language, which, in turn, contribute to the emergence of a certain linguistic picture of the world. A person sees the world through the prism of this picture [1].

The linguistic picture of the world forms the attitude of people to the surrounding reality, norms of behavior, forming a single system of views.

\footnotetext{
* Corresponding author: mariposa-bonita@yandex.ru
} 


\section{Materials and methods}

This article will be based on research questions that investigate the topic at hand. The following part is the material review, which links critical analysis on research of previous studies already written with the research questions. The data collected will then be exhibited in this chapter, the results will then be analyzed in the discussion section. There will be a conclusion at the end of the study summarizing all the research work and proposing additional investigation that could be pursued to further understand the phenomenon. When teaching English at the senior stage, it is important to draw students ' attention to the language features of various languages that serve as a source of borrowings, thereby removing certain difficulties in understanding and using borrowed vocabulary.

The methods of studying the object under study are diverse due to the tasks to be solved. The research uses methods of linguistic observation and description, wordformation and semantic analysis, field structuring, comparative and statistical methods, the method of analyzing dictionary definitions, component and etymological analysis. The reliability and degree of verification of the results of the study, recorded in tables and diagrams, is ensured by the use of quantitative calculation elements.

\section{Results}

The picture of the world as a fundamental factor in the development of national and cultural specifics.

The national-cultural specificity of a particular language is a distinctive feature of one national-cultural community from another. In order to find out the parameters of this difference and its place in the structure of speech communication of this community, it is necessary to turn to such a phenomenon as the picture of the world.

Each language has its own peculiarities of conceptualization of the surrounding world, that is, it has a special picture of the world that is characteristic only for native speakers of this language.

According to Z. D. Popova and I. A. Sternin, the picture of the world is a collection of knowledge about the surrounding reality that has been formed in the public consciousness [1].

There are two types of worldview: direct and indirect.

The direct picture of the world is understood as a picture that is formed as a result of direct knowledge of the surrounding world, that is, knowledge using the senses and abstract thinking [1].

The mediated picture of the world is formed as a result of fixing the concept sphere with the help of secondary sign systems that materialize the immediate picture of the world in the human mind [1].

Each nation has its own specific cultural picture of the world, which is determined by such factors as history, geography, climate, social structure, traditions, beliefs, and so on.

One of the most important functions of a language is to preserve and transmit culture from generation to generation. Based on this, language is a decisive factor in the formation of personality, as well as national character, ethnic community, nation, people [2].

The cultural and linguistic picture of the world plays an important role in teaching of foreign languages.

In this case, the picture of the world of the native language is primary, while the picture of the world of the studied language is secondary, and is superimposed on the picture of the world of the native language, affecting the personality and changing it [2].

Thus, we can conclude that each language is a complex original system that influences the consciousness of native speakers of this language, and is the basis for the formation of 
their picture of the world. The language is not just a reflection of the culture of its people, but also an instrument of this culture, influencing the development of the next generations.

Language personality as the main methodological category in teaching foreign languages

Language serves as a means of communication, a way of expressing and transmitting human thoughts and feelings. However, the essence of language is that it is in that the conceptual image of the world is formed.

A person is a native speaker of a certain language and national mentality. Of particular interest to science at the present stage of development is a person, that is, a specific person who is a native speaker of language and consciousness, and also has a certain worldview [3].

The concept of "language personality" was developed by Yu. N. Karaulov. In his opinion, a language personality should be understood as a person who is capable of creating and perceiving various texts. Y. N. Karaulov developed a level model of the language personality, consisting of three levels:

1) Verbal-semantic, which shows the degree of proficiency in ordinary language;

2) The cognitive level that reflects the linguistic model of the world of a particular person, as well as its culture and vocabulary;

3) The pragmatic level, which deals with the establishment and explanation of the goals and motives that determine the development of the language personality.

This model is not standard, it reflects a generalized type of personality.

In the same culture, there can be many specific language personalities, which differ depending on what level prevails in a particular personality.

The linguistic personality contains a number of components, among which the value, cultural and personal components are usually distinguished.

Let's look at them in more detail.

The value or worldview component includes a set of life values.

The cultural component consists in the development of culture in the study of the language.

The personal component is a set of individual characteristics of each individual person.

V. Krasnykh gives a slightly different classification of the components of the language personality, highlighting the following components:

1) A person who speaks is a person who performs speech activity;

2) The language personality itself is a person who has certain knowledge and ideas, as well as performs speech activity;

3) The speech personality manifests itself in communication, using a certain strategy and set of tools;

4) A communicative person is a specific participant in the act of communication [4].

From the point of view of teaching a foreign language, in the theory of the development of a language personality, special attention is paid to the relationship between language and speech in a person, in connection with which such a concept as "speech personality"is distinguished.

A speech personality is a language personality in terms of real communication. At the same time, the national and cultural specificity of both the language personality and the communication itself is manifested precisely at the level of the speech personality $[4,5]$.

The basis for the formation of a language personality is the language experience of the predecessors. An individual becomes a language personality as a result of his socialization, which is based on the following factors:

- the process by which a person becomes a participant in certain social relations and implements the cultural and historical knowledge of society;

- active speech-thinking activity that takes place according to the norms of culture; 
- assimilation of the laws of the psychology of the people [6].

The existence of a linguistic personality is limited by the framework of a certain culture, which is reflected in the language, in the consciousness of society, in the norms accepted in this society, etc.

One of the characteristic features of methodological science at the present stage is anthropology, which means that the human factor occupies a central place in the process of teaching foreign languages.

In the new scientific paradigm, such a factor is the secondary linguistic personality. A secondary language personality is a person who is able to communicate in a foreign language with representatives of foreign-language cultures.

The gist of teaching foreign languages is to form a secondary language personality and to acquire the ability to communicate in the language being studied.

The conditions for the formation of a secondary language personality are:

- mastering the language itself, acquiring the ability to communicate;

- formation of a picture of the world peculiar to native speakers of the studied language.

Based on this, when teaching foreign languages, it is important to introduce students to the system of linguistic society that is characteristic of native speakers of the language being studied.

Taking into account the concept of secondary language personality, the modern system of teaching foreign languages focuses on the personality of the student.

Thus, the process of teaching foreign languages at the present stage is a process of personal development of the student [7].

The main purpose of language teaching is to form a language personality. At the same time, the basis of the training system is the real communicative, cognitive and cultural needs of the individual. Being a language personality, a person is a native speaker of both language and culture, thus connecting these phenomena.

When teaching a language as a means of communication, the need for a two-way approach to the national and cultural component of the learning process is clearly evident. On the one hand, the student must acquire national-specific knowledge and skills necessary for a foreign-language personality. On the other hand, he needs to acquire national-specific practical skills of the speech personality of a particular language in all its forms of communication.

Language education is a process of acquiring knowledge, skills and abilities, thanks to which it becomes possible to carry out foreign language speech activity. This process is aimed at getting students a new means of communication, learning about someone else's culture and understanding their own culture, developing the ability to successfully conduct a dialogue, as well as instilling tolerance to other cultures and languages. Language education is based on the subject-object interaction of students with foreign linguistic culture, focusing on their native language and culture.

Teaching foreign languages involves the joint activity of students and teachers, in the process of which the development of the individual, its education and upbringing takes place. During the lesson, the teacher transmits his language experience to the students, as a result of which they acquire this speech experience and the ability to use language as a means of communication. Such language proficiency is based on the knowledge, skills and abilities that make up the students ' communicative competence [8].

The main factor of mastering a foreign language is the assimilation of language units of different levels and the ability to adequately apply them in practice. In other words, students must have the ability to recognize other people's speech and generate their own.

According to L. V. Shcherba, language proficiency involves mastering communicative activity in a given language. Proficiency in a foreign language implies proficiency in a number of skills, such as the ability to understand various texts, both oral and written, as 
well as to compose your own texts; the ability to express one thought in several ways; the ability to distinguish between correct and incorrect statements; the ability to use the right words that are adequate for a particular situation [9].

Thus, the knowledge of a foreign language includes several aspects:

- the linguistic aspect is related to the correct use of different language units in speech;

- the situational aspect takes into account the communication situation;

- the social aspect, that is, the relationship with the interlocutor;

When mastering a foreign language, the student must master the following competencies:

a) language competence, that is, the ability to use words in accordance with the norms of the literary language.

b) speech competence, which is the ability to perceive and reproduce statements in the language being studied.

c) communicative competence, which consists in the ability to understand other people's programs of speech behavior and generate their own, adequate to the goals and situations of communication.

The communicative competence includes:

- knowledge of the system of the language being studied,

- skills of using language means of communication,

- knowledge, skills and abilities that allow you to understand and generate foreign language statements according to the communication situation and the communicative task;

- knowledge, skills and abilities, thanks to which it becomes possible to communicate with native speakers of the studied language, according to the national and cultural characteristics existing in their linguistic society [10].

The main purpose of teaching foreign languages is to master the communicative competence, since in order to achieve mutual understanding in communication, it is necessary not only to know the words and be able to use them in speech, but also to have an idea of the social context and have certain cultural and historical knowledge about the country of the language being studied. At the same time, language and speech competencies are an important link on the way to mastering communicative competence [10].

It is customary to distinguish three main groups of goals for teaching foreign languages: communicative, educational and educational.

The communicative goals are to learn language as a system of signs, and to acquire the ability to use language as a means of communication.

Educational goals are focused on improving the level of proficiency in this subject, as well as on improving the overall level of education of students.

Educational goals are aimed at improving the overall cultural level of students, developing interest in the country of the language being studied, as well as forming a creative personality.

The leading position in this complex is occupied by communicative goals, since only on their basis can the successful implementation of educational and educational goals take place.

The goals of training and its content are formed under the influence of society and its needs. For their part, learning objectives influence the choice of ways and methods of learning, and in general, the entire learning process $[8,10]$.

At the present stage of the development of foreign language teaching methods, the learning goals are formulated according to the required level of communicative competence and communicative tasks.

The communicative content of training consists of such components as the scope and situation of communication, the type of communicative task, and speech actions relevant 
for certain types of situations. These components relate to the knowledge, skills, and abilities that are required to perform these speech actions [10].

The communicative content of the training is based on specially selected phonetic, lexical, and grammatical material and is consistent with the necessary speech skills, which makes it possible for students to communicate in a foreign language.

The communicative content of training is closely interrelated with the level of communicative competence, taking a leading position in relation to the language and speech content of training.

The communicative content of the training is a reflection of the communicative-activity approach to the organization of the process of mastering a foreign language. The implementation of this approach is characterized, first of all, by the level of formation of communication skills, language knowledge and speech skills that are necessary to achieve the goals set.

When determining the content of foreign language training, they are usually based on the goals and objectives of training, the levels of communicative competence necessary to achieve these goals. The combination of these factors is the basis for the selection of language material.

Each science has its own basic laws, categories, and principles.

In modern teaching methods, there are three fundamental principles of teaching a foreign language. These include communication skills, taking into account the native language of students, taking into account the culture of the country of the language being studied.

The main idea of communication is to focus the content of training on communication. Communication depends on the nature of communication, on the features of the functioning of the system of the language being studied, on the communicative goals and needs of students.

Communication, or communication, is the central concept of communication-oriented learning. Communication is usually defined as the process of communication between people, including various aspects of culture, society, personality, speech behavior of native speakers, needs, language means and their implementation. Communication can be used to exchange information, influence the interlocutor, establish social contacts, etc. [11].

Communication combines two aspects, language and culture, since language is the main means of communication, and communication itself takes place within the framework of culture. In this regard, in the process of teaching a foreign language, it is necessary to start from the cultural, communicative and situational contexts, and then move on to the language system.

Today, communication skills are a fundamental category of foreign language teaching methods. The purpose of this category is to involve students in the process of communicating with each other to solve various problems, to actively use the language during training, to develop students 'practical skills in a foreign language, as well as to increase students' interest in this academic discipline. Communication is the basis of the content and organization of training, the choice of methods, characterizing all aspects of the educational process. Communication combines the communicative nature of the lessons and the practical assimilation of the theory of language with the support of the native language of the students.

The next principle of teaching a foreign language is the principle of taking into account the native language. The acquisition of a foreign language occurs when it interacts with the native language. A foreign language becomes a self-sufficient means of communication only after overcoming this interaction. 
The principle of accounting for the native language is associated with the comparison of two languages, native and non-native, which is appropriate to identify the factors of the studied language that cause difficulties in the learning process [12].

It is worth mentioning that there is still no single point of view among linguists on the etymological composition of the lexical core and its role in modern English. Many Russian and foreign linguists tend to exaggerate the role of borrowings in modern English. This statement is typical of modern textbooks on lexicology. In them, linguists speak about $70 \%$ of the borrowed words in modern English.

Table 1. The words borrowed from Arabic in English.

\begin{tabular}{|c|}
\hline Names of food \\
\hline 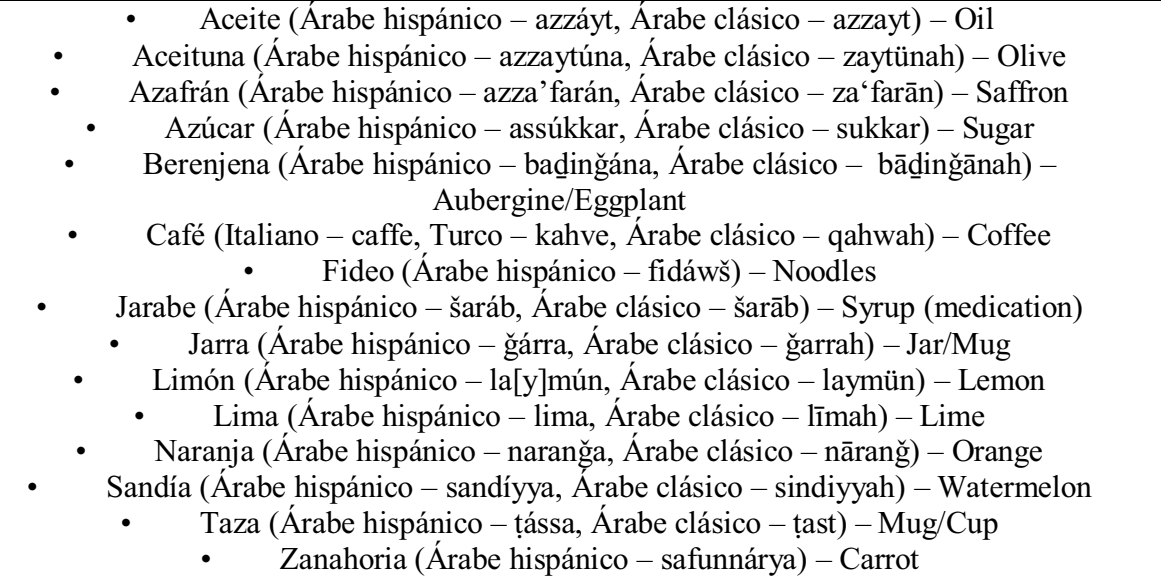 \\
\hline Nature and animals \\
\hline 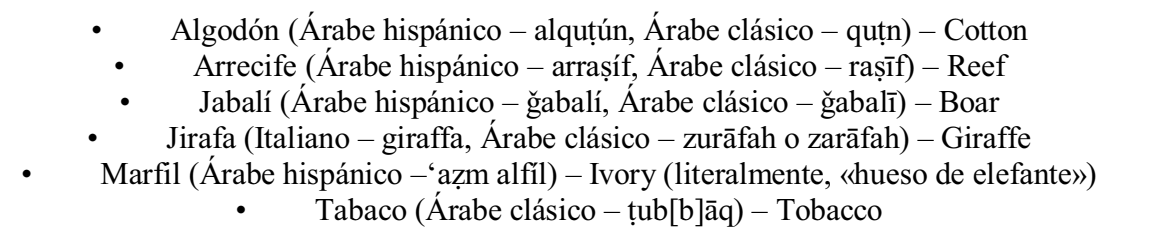 \\
\hline Interjections \\
\hline $\begin{array}{c}\bullet \quad \text { Hasta (Árabe hispánico - hattá) - Until } \\
\text { Ojalá (Árabe hispánico - law šá lláh) - Let’s hope/hopefully/God willing (literalmente «si } \\
\text { Dios quiere») } \\
\bullet \quad \text { ¡Olé! }\end{array}$ \\
\hline Science and hobbies \\
\hline $\begin{array}{l}\text { - Ajedrez (Árabe hispánico - aššațranğ o aššitranğ, Árabe clásico - šițranğ) - Chess } \\
\text { • Alcohol (Árabe hispánico - kuhúl, Árabe clásico - kuhl) - Alcohol } \\
\text { Alfil (Árabe hispánico - alfíl, Árabe clásico - fill) - Bishop (chess) } \\
\text { • Álgebra (Latín - algĕbra, Árabe clásico - alğabru) - Algebra } \\
\text { Algoritmo (Latín - algobarismus, Árabe clásico - hisābu lḡubār) - Algorithm } \\
\bullet \quad \text { Dado (Árabe clásico - a'dād) - Dice }\end{array}$ \\
\hline
\end{tabular}




\section{Other names}

Alcalde (Árabe hispánico - alqádi, Árabe clásico - qāộ̄) - Mayor (literalmente 〈juez»)

Aldea (Árabe hispánico - addóy 'a, Árabe clásico - day 'ah) - Small village

Alfombra (Árabe hispánico - alhánbal, Árabe clásico - hanbal) - Carpet/Rug

Almohada (Árabe hispánico - almuhádda, Árabe clásico - mihhaddah) - Pillow

Alquiler (Árabe hispánico - alkirá or alkirí, Árabe clásico - kirā') - Rent

Asesino (Árabe - haššāššn) - Murderer

Barrio (Árabe hispánico - bárri, Árabe clásico - barrī) - Neighborhood

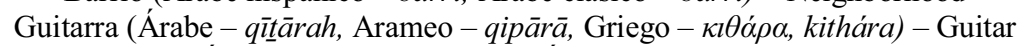

Hazaña (Árabe hispánico - hasána, Árabe clásico - hasanah) - Feat

Máscara (Italiano - maschera, Árabe - masharah) - Mask (literalmente «objeto de risa»)

Mazmorra (Árabe hispánico - matmúra, Árabe clásico - mațūrah) - Dungeon

Momia (Árabe clásico - mūmiyā) - Mummy

Noria (Árabe hispánico - na úra, Árabe clásico - nā ūrah) - Waterwheel/Ferris wheel

Tarea (Árabe hispánico - țaríha, raíz del Árabe clásico - \{trh $\}$ ) - Task

\section{Discussion}

Language is a mobile system that changes over time, as evidenced by our analysis of the etymological development of language. For the reliability of the theoretical sources we have studied, we have analyzed modern textbooks of the English language. In the course of the study, more than two hundred sentences containing elements of borrowed vocabulary were selected by the continuous sampling method. The borrowed vocabulary is represented by various lexico-semantic groups [13].

The borrowed vocabulary has a number of certain characteristics that are not typical of typical English. Referring to the material we have collected, as well as relying on the theoretical sources of domestic and foreign linguists, we can identify the main criteria that must be taken into account when submitting material in English lessons in high school. First of all, it's spelling. The borrowed vocabulary is characterized by a special spelling characteristic of the source language. Taking this important aspect into account, we have developed a system of lexical exercises that can help students differentiate between borrowed and native English vocabulary, as well as guess from which language a particular word came and to which part of speech it refers $[14,15]$.

It is necessary to emphasize that not always only the vocabulary is borrowed. In the course of national interaction of cultures, languages can even exchange word-forming elements. In most cases, these elements are assimilated over time in the recipient language, becoming similar to the grammatical and syntactic rules of the recipient language.

The native prefixes are: mis -, un -, out -, up -, under -, over -, with-. There are far fewer native prefixes in English than there are borrowed ones.

From the point of view of possible values of selection, such as: negative prefixes un-, in-, dis-; prefix denoting the precedence: fore-, pre-, ex-; redundancy: over-, hyper-, arch-, per-, supra-; failure: under-, sub-, hypo-; resistance and the opposite: counter-, contra-, anti-

In the system of suffix formation of nouns, it is possible to distinguish, for example, suffixes denoting the names of persons: -er, -est, -ee, -ess, -ite, -ese, -ster; female beings: ix, -ine, -ette-, -ess; suffixes with the meaning "property, state, quality; "collectivity": -ery; "defined action": -al, -ance, -ice, -ing, -y, etc.

From the point of view of valence, it is relevant to the basis of which part of speech this affix is attached to. For example, the prefix arch-is combined only with the basics of nouns 
(archbishop, archenemy), the prefix dis - is combined with verbs (deny, discover, displease) and nouns (dismember, discourage).

The suffix -ish can be combined with the basics of nouns (boyish, womanish) and with the basics of adjectives (reddish).

From the point of view of productivity, affixes are distinguished: productive-actively involved in the formation of new words at the current stage of language development, whose derivatives are numerous and unproductive, for example: unproductive-limited in the formation of new words, the derivatives of which belong to the number of little-used lexemes, for example: -ie (deccie, druggie, wrinklie, foodie); -ese (Japanese, Milanese, Veronese); unproductive - not involved in the formation of new words in modern English, but nevertheless distinguished as significant morphemes in words, for example: -ard (dullard); en- (enrich) -th (growth); -dom (freedom); -hood (brotherhood); -ship (friendship); dead - in the course of historical development, they merged with the root and at the present stage of language development are not distinguished as word - forming morphemes, for example: for- (forbid);- lock (wedlock);- red (hatred);- t (flight, gift);- er (chatter, glimmer); - k (walk, talk); -id (horrid); -ile (fragile).

In our opinion, we should pay attention to the linguistic features of the various languages that serve as a source of borrowing, thereby removing certain difficulties in understanding and using the borrowed vocabulary. The correct presentation of the material is necessary - brief information about the borrowed elements and direct development of the material.

\section{Conclusion}

The language is undergoing changes associated with borrowing words from the dominant language constantly adjusting itself. With the development of social, political, economic and cultural conditions with other societies, there is a "mixing of languages" or "language contact". This process affects the structure or vocabulary of one of the languages. Since contact occurs through the social and speech interaction of native speakers, the result is either minor changes in vocabulary or significant structural changes at all language levels.

The vocabulary of any language is rich in a number of borrowed words, which are very diverse both in their composition and in the degree of penetration into the language they are borrowed from. Of all the units of a language - phonetic, grammatical, and lexical-words are usually the most easily borrowed due to their General mobility. However, in the vocabulary of any language there are, as we already know, different "layers", different categories of words that are borrowed in different ways.

Many Russian and foreign linguists tend to exaggerate the role of borrowings in modern English. This statement is typical of modern textbooks on lexicology. In them, linguists speak about $70 \%$ of the borrowed words in modern English.

Each science has its own basic laws, categories, and principles.

In modern teaching methods, there are three fundamental principles of teaching a foreign language. These include communication skills, taking into account the native language of students, taking into account the culture of the country of the language being studied.

The main idea of communication is to focus the content of training on communication. Communication depends on the nature of communication, on the features of the functioning of the system of the language being studied, on the communicative goals and needs of students.

Communication, or communication, is the central concept of communication-oriented learning. Communication is usually defined as the process of communication between people, including various aspects of culture, society, personality, speech behavior of native 
speakers, needs, language means and their implementation. Communication can be used to exchange information, influence the interlocutor, establish social contacts, etc.

Communication combines two aspects, language and culture, since language is the main means of communication, and communication itself takes place within the framework of culture. So we suppose that it is necessary to start from the cultural, communicative and situational contexts, and then move on to the language system [15]

Today, communication skills are a fundamental category of foreign language teaching methods. The purpose of this category is to involve students in the process of communicating with each other to solve various problems, to actively use the language during training, to develop students 'practical skills in a foreign language, as well as to increase students' interest in this academic discipline. Communication is the basis of the content and organization of training, the choice of methods, characterizing all aspects of the educational process. Communication combines the communicative nature of the lessons and the practical assimilation of the theory of language with the support of Russian.

The acquisition of a foreign language occurs when it interacts with the native language. A foreign language becomes a self-sufficient means of communication only after overcoming this interaction.

\section{References}

1. I.A. Sternin, Speech effects (Polygraph, Voronezh, 2001)

2. S.G. Ter-Minasova, Word combination in scientific-linguistic and didactic aspects (LKI, Moscow, 2007)

3. I.P. Susov, Linguistic pragmatics (Nova Kniga, Vinnytsia, 2009)

4. E.E. Sakharova, N.P. Revyakina, SHS Web of Conferences (2020), DOI: https://doi.org/10.1051/e3sconf/20202101804 (2020)

5. A.I. Smirnitsky, Syntax of the English language (Librocom, Moscow, 2009)

6. Z.G. Proshina, International Journal Social Sciences and Humanities, 12(2), 242-252 (2010)

7. I.N. Zhukova, Dictionary of terms of intercultural communication (Flinta: Nauka, Moscow, 2013 )

8. S.V.Pervukhina, V.I. Demchenko, ES3 Web of Conferences, 210, 18033, 1-10 (2020), https://doi.org/10.1051/e3sconf/202021018033

9. T.I. Erofeeva, Vestn. Perm. University, 1(7), 21-25 (2010)

10. T. Mikheeva, E. Murugova, Y. Morozova, V. Demchenko, In Proceedings of 14th International Technology, Education and Development Conference, 1211-1215 (2020), doi:10.21125/inted.2020.0417 (2020)

11. S.V. Pervukhina, G.I. Radchenko, E3S Web of Conferences, 210, 18036 1-10 (2020), https://doi.org/10.1051/e3sconf/202021018036

12. T.B. Mikheeva, In Proceedings of IX International Conference "Word, Utterance, Text: Cognitive, Pragmatic and Cultural Aspects", Social \& Behavioural Sciences, 109-114 (2018), doi: HTTP://DX.DOI.ORG/10.15405/EPSBS.2018.04.02.16

13. T.B. Mikheeva, E.V. Murugova, SHS Web Conf., 70, 07003 (2018), doi: https://doi.org/10.1051/shsconf/20197007003

14. V.I. Demchenko, K. Khoroshevskaya, K. Krukov, 1079, 032089 (2021), doi: https://iopscience.iop.org./article/10.1088/1757-899X/1079/3/032089. (2021) 
15. E. Egorova, N. Bulankina, O. Mishutina,V. Tsybaneva, In Proceedings of INTED2021 (2021), doi: 10.21125/inted.2021.0159 